\title{
ECONOMICS
}

\section{REGIONAL DISPARITY OF EMBEDDED CARBON FOOTPRINT AND ITS SOURCES IN CHINA: A CONSUMPTION PERSPECTIVE}

\section{by}

Jin Fan

School of Management

University of Science and Technology of China

\author{
Yanrui Wu \\ Business School \\ University of Western Australia
}

Xiumei Guo

Curtin University Sustainability Policy Institute Curtin University of Technology

Dingtao Zhao

Curtin University Sustainability Policy Institute Curtin University of Technology

Dora Marinova

Curtin University Sustainability Policy Institute Curtin University of Technology 


\title{
REGIONAL DISPARITY OF EMBEDDED CARBON FOOTPRINT AND ITS SOURCES IN CHINA: A CONSUMPTION PERSPECTIVE
}

\author{
Jin Fan ${ }^{\mathrm{a}}$, Yanrui Wu ${ }^{\mathrm{b}}$, Xiumei Guo ${ }^{\mathrm{c}}$, Dingtao Zhao ${ }^{\mathrm{c}}$ and Dora Marinova ${ }^{\mathrm{c}}$
}

\section{DISCUSSION PAPER 15.06}

\begin{abstract}
:
Carbon emission reduction could be achieved through extensive cooperation between relevant groups such as businesses, governments and consumers. Generally, carbon emissions stem from consumer behavior. To tackle the increasingly serious energy crisis and climate change in China, it is thus vital to control carbon emissions generated by the country's urban consumers. From a consumption perspective, we utilize a self-organizing feature map (SOFM) model to analyze the spatial differentiation of per capita embedded carbon footprint (ECF) in urban China. We found that the spatial differentiation is significant with the per capita ECF of the east coastal area at a high level and that per capita disposable income is the key factor affecting ECF. Based on these findings, potential business opportunities to develop low-carbon products are discussed.
\end{abstract}

Key words: China, consumption, embedded carbon footprint, energy, regional disparity, self-organizing feature map model

\footnotetext{
${ }^{\mathrm{a}}$ School of Management, University of Science and Technology of China. ${ }^{\mathrm{b}}$ Business School, University of Western Australia (The corresponding author: yanrui.wu@uwa.edu.au). ${ }^{\mathrm{c}}$ Curtin University Sustainability Policy Institute, Curtin University of Technology.

Citation: Fan, Jin, Yanrui Wu, Xiumei Guo, Dingtao Zhao and Dora Marinova, 2015, "Regional Disparity of Embedded Carbon Footprint and Its Sources in China: A Consumption Perspective”, Asia Pacific Business Review, 21(1), 130-46.

Acknowledgements: The authors acknowledge the National Natural Science Foundation of China (Grant No. 71301157) and the China Postdoctoral Fellowship Fund (Grant No. 2013M531533) for their generous financial support. They also thank an anonymous referee, Hongyi Lai and editor of the journal for their helpful comments and suggestions on early drafts of the paper.
} 


\section{INTRODUCTION}

Carbon dioxide $\left(\mathrm{CO}_{2}\right)$ is one of the major contributors to climate change which is a global problem (Manne and Richels, 1991). The control of carbon emissions produced via urban consumption is the most important task for China in dealing with the country's increasingly serious environmental crisis and climate change (Fan et al., 2013). At present, about $70 \%$ of carbon emissions in China are generated in the production and transportation of goods while about 30\% are produced through urban consumption (NBSC, 2013). The experience of developed countries shows that urbanization will lead to a sharp increase in carbon emissions. The growth rate of energy consumption in urban China has reached 8\%, exceeding the country's total energy consumption growth of 7\% per annum (NBSC, 2013). Thus energy saving and emission reduction in the consumption sector will play an important role in China's overall course of energy conservation and emission reduction.

Lenzen and Murray (2001) argued that the main factor driving emission growth is the increase of consumption, which may offset the reduction effect of technological improvement and industrial upgrading. Through analyzing the relationship between energy consumption and lifestyle in 20,000 American families, Adua (2010) derived a similar conclusion. This effect is called the "Jevons Paradox", that is, the improvement of energy efficiency could lead to higher energy consumption if a change of lifestyle is not achieved (Figge et al., 2014).

We will use carbon footprint to measure carbon emissions from consumption of goods and services. The carbon footprint is a measure of the amount of carbon dioxide emitted through the combustion of fossil energy, which is the main source of anthropogenic emission of greenhouse gases (GHGs) for all countries in the world. China is no exception. The majority of the total carbon emissions in China is energy induced ( $\mathrm{Li}$ et al., 2012). The carbon footprint for a consumer is the amount of $\mathrm{CO}_{2}$ emitted either directly or indirectly as a result of the consumer's everyday activities. Therefore it can be divided into direct carbon footprint (DCF) and embedded carbon footprint (ECF). DCF is the direct carbon emission produced by gas, coal and fuel 
used in the consumption process whereas ECF refers to carbon emissions generated in the whole life cycle (development, production, circulation, and use and recycling) of goods or services that are ultimately consumed, which is not easily perceived and difficult to calculate. ECF is calculated from the perspective of lifestyle and socialbehavior (LSB) (Fan et al., 2012). Compared with the physical and technical economic models, the ECF based on LSB puts more emphasis on consumption factors, which reflects the actual sources of emissions.

The rest of the study begins with a review of the related literature. This is followed by description of the main research questions. Subsequently issues associated with research methodology are discussed. The data issues and preliminary findings are described next which is followed with more detailed discussions. Policy and business implications are then explored. The final section concludes the study.

\section{LITERATURE}

Changing consumer behaviour is generally considered to be an option to reduce the emissions of GHGs (VROM, 1999). Since the 1990s, literatures relating to issues concerning energy and carbon emissions from a consumption perspective have emerged. For example, Vringer and Blok (1995, 2000) investigated the energy consumption structure of Dutch families from 1948 -1996. Their results indicate that household energy requirement could be reduced if their consumption patterns were changed. Reinders et al. (2003) examined the relationship between household consumption expenditure and energy consumption in eleven EU members. They found that indirect energy consumption and household expenditure are linearly correlated. Based on the theoretical framework of the environmental pressure prediction model on consumption, Rood et al. (2003) argued that the factors determining consumption patterns and corresponding environmental pressure are economic growth, changes of population and social structure, technological advance, and so on. Further, through structural path analysis, Lenzen et al. (2004) investigated the factors that influence residential energy demand in Sydney, Australia. Druckman 
and Jackson (2009) analyzed the relationship between household expenditure and carbon emissions in UK households, and found that while the "dash for gas" technology occurred in the 1990s in the UK, there was no evident decoupling relationship between carbon emissions and expenditure. In addition, Weber and Matthews (2008) and Herrmann and Hauschild (2009) examined how international trade influences the household carbon footprint.

Furthermore, Benders et al. (2006) analyzed the energy consumption of 300 families in Groningen, Holland, and found that behavior intervention can reduce the direct energy consumption of the experimental groups by about $8.5 \%$ compared with the control groups; with no significant effect on indirect energy consumption. Abrahamse et al. (2007) and Abrahamse and Steg (2009) derived a similar conclusion. In addition, Steg (2008) discussed the role of information and structure strategy for family energy conservation from a psychological perspective. These studies focus on the analysis of household energy consumption or carbon footprint pertaining to different consumer behaviors and consumption patterns. However, little attention is given to the factors that influence the ECF in China. The purpose of our study is to extend the work in this area.

\section{RESEARCH QUESTIONS}

Previous literature has shown that income is an important factor for household emissions (Reinders et al., 2003; Druckman and Jackson, 2009). Lenzen et al. (2004) argued that growth in per capita income and the resulting consumption of goods and services represent the main drivers for growth in the energy requirements underpinning consumption. In addition to the economic variable, other factors such as geographic location and food habits need to be considered in the analysis of emissions (Pachauri, 2004). As for China, first, the economies of the east coastal area are more developed than those of the central and western regions. In 2012, the per capita disposable income in the eastern provinces is $¥ 29,622$, which is almost 1.5 times as much as that in the central and western provinces (NBSC, 2013). Second, different 
areas have their own dietary habits and hence consumption patterns. Third, the temperature in China's cities differs greatly during winter. It is much colder in the northern cities than in the southern cities. This factor might affect the ECF. Given these variations, we propose three hypotheses as follows:

Hypothesis 1: The spatial differentiation of urban residents' per capita ECF in China is significant.

Hypothesis 2: Per capita disposable income is the key factor affecting the ECF in urban China.

Hypothesis 3: Other factors, such as geographic location and dietary habits, might influence the ECF.

The objective of this study is to explore the regional disparity of ECF and its sources in urban China from the perspective of consumption. We focus on urban ECF for two reasons. On the one hand, the dominant position of urban residents' consumption in domestic consumption is continuously strengthened. On the other hand, the data of urban consumption is available. More specifically, the main research questions addressed in our study include:

(1) What is the spatial differentiation feature of per capita ECF in urban China?

(2) What factors may influence the per capita ECF?

(3) What implications of the findings are there for relevant businesses?

\section{METHODOLOGY}

The potential factors affecting China's ECF can be investigated using conventional regression techniques. For instance, through regression analysis, we can determine the direction and level influenced by the independent variables. But, the subjectivity of variable selection is strong and may lead to the exclusion of various important variables. In addition, traditional regression analysis generally needs to meet the harsh conditions of hypothesis testing. To avoid these problems, we adopt the framework of a self-organizing feature map (SOFM) model in this study. The SOFM is a neural network model for exploring and visualizing the patterns of high dimensional input 
vectors in input data set. It was first introduced to the neural network community by Kohonen (1982). The SOFM consists of two layers: the input layer and the output layer (Figure 1). The input layer contains one unit for each variable (such as per capita ECF and per capita disposable income) of the input vectors. The output layer consists of several neurons, each of which has an associated $d$-dimensional weight vector (that is, a neuron weight vector). The dimension $d$ is the same as the dimension of the input vectors. The output layer neurons are connected to every unit in the input layer through the weight vectors (Kalteh et al., 2008). In addition, the output layer neurons with similar weights are placed together.

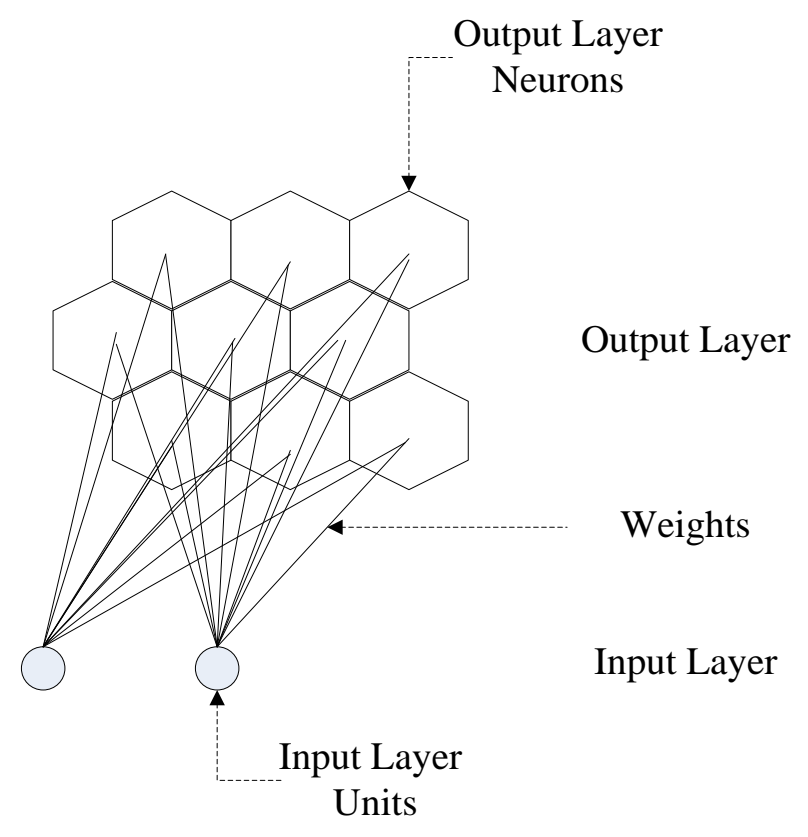

Figure 1 The SOFM architecture

Source: Authors' own drawing.

To form a SOFM, an input vector $i$ from the input data set is selected randomly and an iterative procedure is executed. First, this procedure is started by calculating the distance between the input vector $i$, and each of the output layer neuron weight vectors. The neuron with the closest distance to the input vector $i$ is called a winner neuron. Then the weight vector of the winner neuron and its neighboring neurons are updated in order to be moved closer to the input vector. This process is called the 
training procedure which is repeated until convergence, that is, until the weight vector of each output layer neuron is stable. A prominent feature of SOFM is that it not only makes the winner neurons to learn but also adjusts the weight vectors of their neighboring neurons. In this way, neurons located close to each other in the output layer have similar input patterns (Kalteh et al., 2008). By comparing the corresponding output layer neuron weights of different dimensions, we can judge the correlation among these dimensions (Mostafa, 2010). Furthermore, based on the correlation analysis, factors that affect these dimensions are revealed through the analysis of anomalous characteristics of neuron weights. Therefore the SOFM analysis can identify as many influencing factors as possible. In addition, the SOFM analysis can be conducted without the rigid assumptions of linearity or normality associated with traditional regression techniques, and it has no clear restrictions on sample capacity, which is in line with the characteristics of data for this study.

\section{Model formulation}

Weber and Matthews (2008) and Druckman and Jackson (2009) attribute ECF to functional uses that make up modern urban lifestyles such as housing, food and catering, clothing and footwear, health and hygiene, recreation and leisure, education, communications and commuting. According to Fan et al. (2012), the ECF of food and catering, and clothing and footwear can be classified as subsistence-oriented emissions, and that of health and hygiene, recreation and leisure, and education can be classified as development-oriented emissions. Other consumption categories such as housing (including residential energy) and personal transport have much higher emission intensities. Thus ECF can be divided into and examined in four classes, namely the ECF of 1) food and clothing, 2) housing (including residential energy), 3) health, education and recreation and 4) transport (the ECF calculation technique is detailed in Fan et al. (2012). Based on this classification, we use the proportion of ECF in each category (of the four groups), per capita ECF and per capita disposable income of the provinces as the six conceptual dimensions. Each conceptual dimension may include one or more sub-items. For instance, the housing ECF includes the ECF 
of electricity, heating, and household articles, and so on.

\section{Model development and its application}

While SOFM is usually used for clustering analysis (Moreno et al., 2006; Silver and Shmoish, 2008; Mostafa, 2010), it can also be used to conduct spatial differentiation and correlation analysis. In our SOFM model, provinces with six conceptual dimensions are treated as input vectors and the model will group them into different clusters. A cluster may include one or more output layer neurons. It can judge the spatial differentiation characteristics of different provinces through the study of the relationship of output layer neurons. The shading of the connecting polygons between output layer neurons refers to the topology distance. The darker the shading is, the greater the distance; and the brighter, the smaller the distance. Closer physical locations of neurons have similar input patterns (Kalteh et al., 2008). Therefore, through observing the shading of the connecting polygons we can group the neurons into different clusters and analyze the characteristics of spatial differentiation for different provinces.

In SOFM, the location of the same province is fixed in different conceptual dimensions. For example, Provinces 1 and 2 are located in neuron 1, and provinces 3 and 4 are located in neuron 2, respectively (Figure 2). According to this feature, correlation analysis can be implemented by comparing neuron weights. We use the color of neurons for neuron weights. The brighter the neurons are, the greater the neuron weights in conceptual dimensions. If neuron weight distributions are similar in two conceptual dimensions, this demonstrates that the two dimensions are positively related (Figure 2-a). If two conceptual dimensions are complementary, that is to say, some neurons' color is brighter in conceptual dimension " $x$ ”, but the corresponding neurons' color in conceptual dimension " $y$ " is darker, this means that the two conceptual dimensions are negatively related (Figure 2-b).

Based on the correlation analysis, a factor analysis can be conducted. Assuming conceptual dimension " $x$ " is relevant to " $y$ ", and furthermore, if the color of two neurons is similar in dimension " $x$ ", their color will also be similar in dimension " $y$ ", 
according to correlation analysis. If their color is different we can call this case as an abnormal situation. Discussing the abnormal results will help explain the influencing factors of ECF. Assuming neuron "1" is brighter than neuron " 2 ", by comparing the corresponding sub-items in the maximum ECF province in neuron " 1 " and that in the minimum ECF province in neuron "2", we can provide an assessment of the influencing factors of ECF. For instance, if we observe that a specific sub-item in the maximum ECF province in neuron "1"is much higher than that in the minimum ECF province in neuron " 2 ”, we can examine the factors underlying this result.

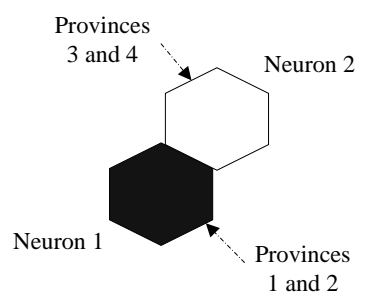

Dimension $\mathrm{x}$

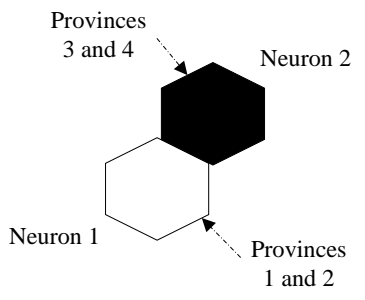

Dimension $\mathrm{x}$

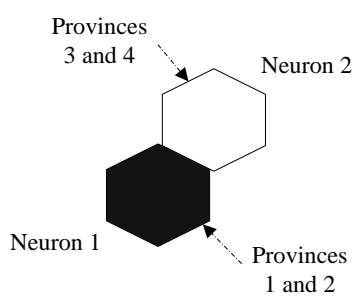

Dimension y

(a)

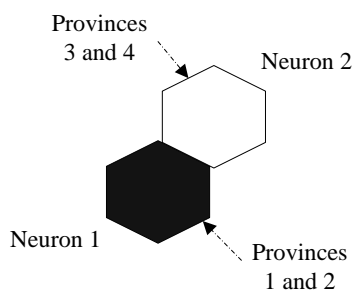

Dimension y

(b)

Figure 2 Feature maps

Source: Authors' own drawing.

\section{FINDINGS}

\section{Data issues}

The emissions conversion factors for coal, coke, crude oil, gasoline, kerosene, diesel oil, fuel oil and natural gas are drawn from IPCC. Data for energy consumption, 
conversion of energy into standard coal and other conversion information are from the China Energy Statistical Yearbook (2007) (NBSC, 2008). There is no specific data for energy consumption by service sectors in China Energy Statistical Yearbook. However the input-output table provides details of the service sectors, allowing us to identify carbon emissions from corresponding sectors according to the sectors' output shares. Urban consumption data is obtained from the China Urban Life and Price Yearbook (2007) (NBSC, 2008). In order to optimize the data interface between consumption items and producing sectors, we employ China's 2007 input-output table with 42 sectors.

Through adopting the input-output model of carbon emissions proposed by Bicknell et al. (1998) and later used by many researchers such as Ferng (2001; 2009), Turner et al. (2007), Begum et al. (2009), Fan et al. (2012), and Das and Paul (2014), we calculate urban residents' ECF for each province and use SOFM to analyze the spatial differentiation characteristics of per capita ECF. To help provide benchmark comparisons and expand our understanding of the spatial differentiation of ECF we rank the per capita ECF of the 31 provinces, autonomous regions and municipalities in China. In Table 1, the per capita ECF ranges from 1.16 tons in Tibet to 2.69 tons in Shanghai. Of the 31 provinces, autonomous regions and municipalities, there are ten with per capita ECF above the national average (1.74 tons). There are 21 others below this national average.

There are many software packages available for analyzing SOFM models. We chose MATLAB R2008a as our programming tool as it offers many advantages. This software contains a variety of signal processing and statistical tools, which help users in generating a variety of signals and plotting them (Bachu et al., 2008). It applies artificial intelligence techniques to automatically identify the efficient SOFM clusters. The six indicators shown in Table 1 are treated as the six conceptual dimensions. The neurons are connected to every variable in the input layer through neuron weights (Figure 1). The number of output layer neurons is determined by the desired number of classes, which are independent of the number of the variables ( $\mathrm{Lu}$ and Lo, 2002). After developing and evaluating a series of SOFMs (4, 9, 16 and 25 neurons), the 
model with four neurons performed reasonably well in the clustering and factor analysis and hence is selected as the preferred model.

Table 1 Per capita ECF of each province in China

\begin{tabular}{ccccccc}
\hline & I & II & III & IV & V & VI \\
\hline Shanghai & 0.26 & 0.32 & 0.19 & 0.23 & 2.69 & 23.62 \\
Tianjin & 0.19 & 0.38 & 0.33 & 0.09 & 2.49 & 16.36 \\
Beijing & 0.23 & 0.23 & 0.36 & 0.18 & 2.49 & 21.99 \\
Guangdong & 0.24 & 0.30 & 0.23 & 0.23 & 2.47 & 17.70 \\
Zhejiang & 0.26 & 0.33 & 0.25 & 0.17 & 2.23 & 20.57 \\
Jilin & 0.18 & 0.44 & 0.27 & 0.10 & 1.93 & 11.29 \\
Liaoning & 0.22 & 0.41 & 0.26 & 0.11 & 1.92 & 12.30 \\
Fujian & 0.30 & 0.40 & 0.17 & 0.13 & 1.83 & 15.51 \\
Chongqing & 0.24 & 0.33 & 0.30 & 0.13 & 1.80 & 12.59 \\
Hebei & 0.19 & 0.40 & 0.33 & 0.08 & 1.78 & 11.69 \\
\hline National Average & 0.25 & 0.33 & 0.28 & 0.14 & 1.74 & 13.79 \\
\hline Shandong & 0.23 & 0.39 & 0.26 & 0.13 & 1.74 & 14.26 \\
Ningxia & 0.19 & 0.36 & 0.33 & 0.11 & 1.66 & 10.86 \\
Inner Mongolia & 0.20 & 0.36 & 0.31 & 0.13 & 1.65 & 12.38 \\
Jiangsu & 0.29 & 0.29 & 0.28 & 0.14 & 1.58 & 16.38 \\
Heilongjiang & 0.20 & 0.38 & 0.32 & 0.10 & 1.57 & 10.25 \\
Shanxi & 0.22 & 0.31 & 0.36 & 0.11 & 1.57 & 10.76 \\
Hunan & 0.25 & 0.31 & 0.32 & 0.13 & 1.56 & 12.29 \\
Hainan & 0.30 & 0.26 & 0.25 & 0.19 & 1.48 & 11.00 \\
Gansu & 0.22 & 0.37 & 0.29 & 0.12 & 1.48 & 10.01 \\
Shanxi & 0.21 & 0.39 & 0.31 & 0.10 & 1.47 & 11.56 \\
Hubei & 0.28 & 0.34 & 0.25 & 0.12 & 1.46 & 11.49 \\
Sichuan & 0.29 & 0.29 & 0.29 & 0.13 & 1.45 & 11.10 \\
Henan & 0.23 & 0.34 & 0.35 & 0.08 & 1.42 & 11.48 \\
Anhui & 0.28 & 0.30 & 0.29 & 0.12 & 1.42 & 11.47 \\
Guangxi & 0.29 & 0.30 & 0.28 & 0.13 & 1.42 & 12.20 \\
Xinjiang & 0.23 & 0.35 & 0.27 & 0.16 & 1.41 & 10.31 \\
Qinghai & 0.23 & 0.36 & 0.26 & 0.15 & 1.37 & 10.28 \\
Yunnan & 0.29 & 0.24 & 0.35 & 0.12 & 1.35 & 11.50 \\
Jiangxi & 0.31 & 0.36 & 0.24 & 0.09 & 1.27 & 11.45 \\
Guizhou & 0.29 & 0.36 & 0.22 & 0.13 & 1.27 & 10.68 \\
Tibet & 0.39 & 0.31 & 0.17 & 0.14 & 1.16 & 11.13 \\
\hline
\end{tabular}

Notes: Columns I to IV present the proportion of ECF of 1) food and clothing, 2) housing (including residential energy), 3) health, education and recreation, and 4) transport. Column V gives the per capita ECF (metric tons). Column VI presents per capita disposable income (¥1,000). Source: Authors’ own calculation. 


\section{Preliminary findings}

The SOFM cluster results are shown in Figure 3. The neurons stand for the sets of the provinces. There are $18,5,1$, and 7 provinces located in neurons $1,2,3$ and 4 , respectively. The color of the connecting polygons between the neurons refers to the topology distance of them. The darker the color is, the greater the distance; and the brighter, the smaller the distance. In this figure we can see that the color of the connecting polygons between neurons 2 and 3 is brighter than others', which shows that the distances between them are closer. So the above four neurons can be divided into three categories, namely cluster I (neuron 1), cluster II (neurons 2 and 3) and cluster III (neuron 4). The order of the clusters stands for the per capita ECF of them. Table 2 and Figure 4 show the analysis results.

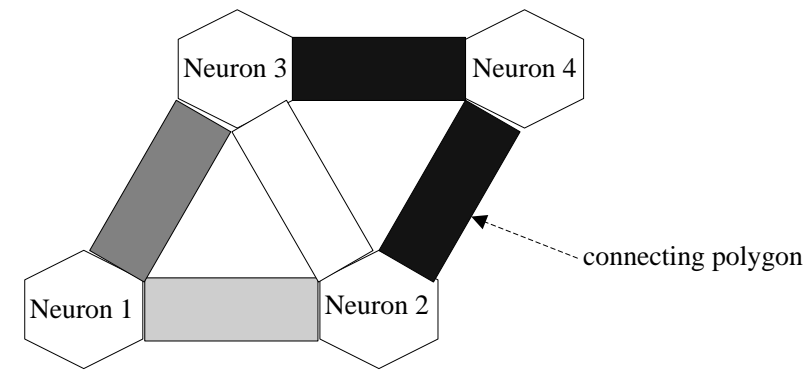

Notes: The numbers denote neurons 1, 2, 3 and 4, respectively.

Source: Authors’ own calculation and the weights are generated in MATLAB R2008a.

Figure 3 The distance among neurons

The economies of Beijing, Shanghai, Zhejiang, Guangdong, Tianjin, Jiangsu and Fujian are the most developed in China. Their per capita ECF is 2.2 tons, which is almost 1.3 times the national average. This group forms cluster III. The regions in cluster III are all in the eastern coastal area. These regions account for 31\% of China's urban population and 39\% of the country's total ECF. This cluster is characterized with a high disposable income and a clearly above average ECF level. From the perspective of consumption, the eastern coastal area should be considered as the main regulatory target for carbon reduction. 
Table 2 Classification of clusters

\begin{tabular}{ccc}
\hline Clusters & Neurons & Provinces, Autonomous Regions and Municipalities \\
\hline I & 1 & $\begin{array}{r}\text { Heilongjiang, Jilin, Hebei, Shanxi, Henan, Anhui, Hubei, } \\
\text { Jiangxi, Xinjiang, Qinghai, Gansu, Ningxia, Shanxi, } \\
\text { Sichuan, Guizhou, Yunnan, Hainan, Tibet }\end{array}$ \\
II & 2 & Guangxi, Hunan, Liaoning, Inner Mongolia, Chongqing \\
\cline { 2 - 3 } & 3 & \\
III & & Beijing, Shanghai, Zhejiang, Guangdong, Tianjin, Jiangsu, \\
Fujian
\end{tabular}

Source: Authors’ own work.

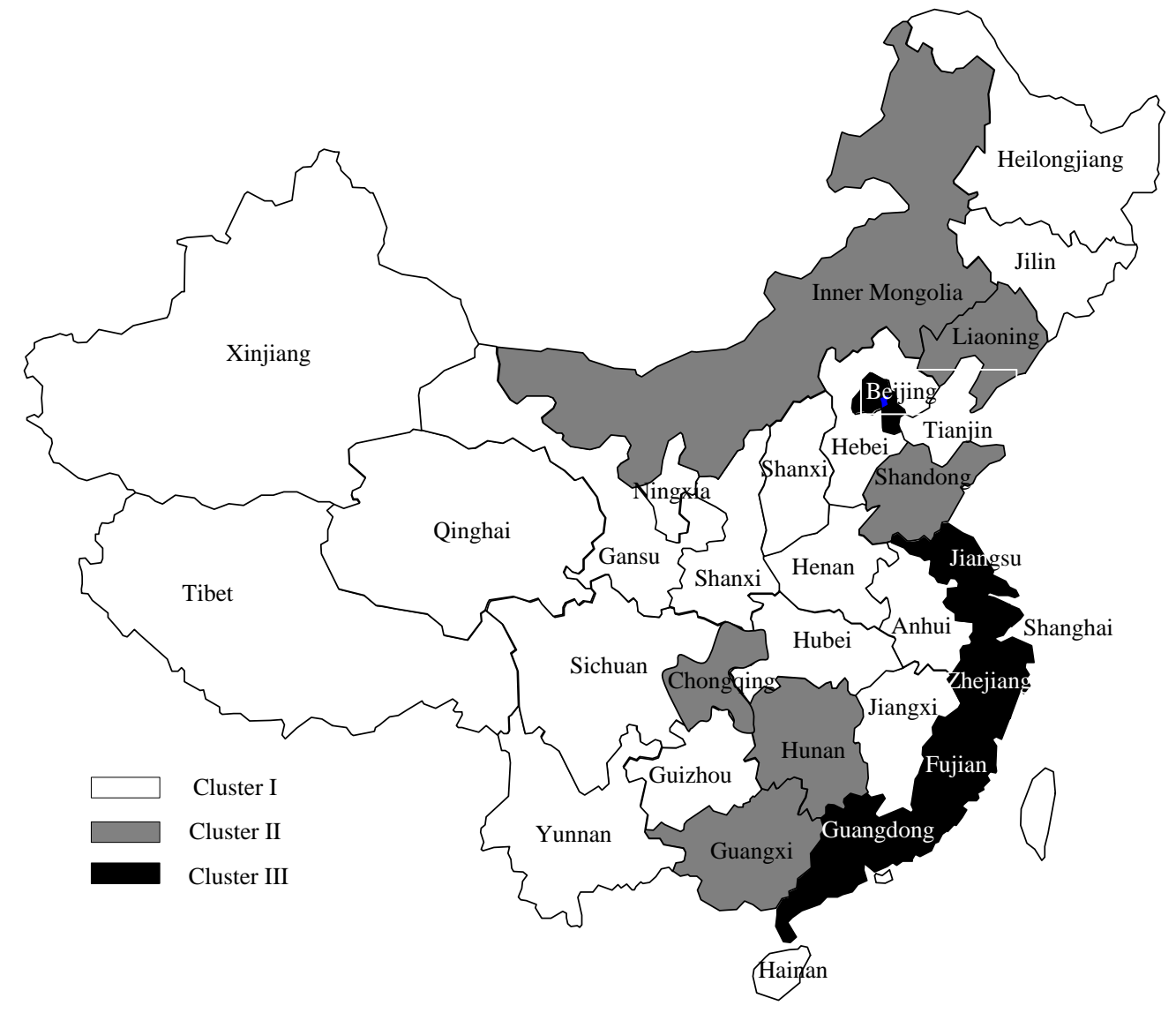

Figure 4 Distribution of clusters based on SOFM

Source: Authors' own drawing.

The regions in cluster II are located in the north and south of China. Their per capita ECF is 1.7 tons, which is about the national average (Table 1). However, the 
cultural, geographical and climatic characteristics in cluster II differ greatly. Cluster I includes the other 18 regions. The economies of these areas are less developed. Their average per capita ECF is 1.5 tons, which is below the national average (Table 1). In general, the per capita ECF in China is highly unbalanced across the provinces. For example, the per capita ECF in Shanghai is about twice as high as that in the less developed provinces. Thus, hypothesis 1 is supported. Provincial ECF in China, however, can be expected to change in response to changes in income distribution pattern. Over time, as regional income disparity falls, poor areas will catch up with rich regions (Crompton and $\mathrm{Wu}, 2005)$. This catch-up effect will also affect China's overall ECF in the future.

China's ECF has also been influenced by the growth in demand for energy-intensive products such as automobiles and air conditioners. In 1990, there were only 0.8 million private vehicles in China (Wang et al., 2007). However in 2011, the total number of private vehicles reached 78.7 million (NBSC, 2012). The ownership of air conditioners per 100 urban households has increased from $0.34 \%$ in 1990 to $122.00 \%$ in 2011 (NBSC, 2012). These features of China's ECF imply that strong growth in ECF will continue in the future. This growth is due to the expected expansion of the Chinese economy and the strategy of stimulating economic growth through domestic demand expansion (NDRC, 2011).

\section{DISCUSSION}

In SOFM, the neurons, which share similar information, are organized in close color proximity to each other (Mostafa, 2010). In accordance with Figure 3, the neurons (hexagons) in Figure 5 represent the sets of the provinces. The brighter the neurons are, the greater the neuron weights. The weight vectors give a representation of the distribution of the input vectors in an ordered fashion (Kalteh et al., 2008). Thus, Figure 5 shows the distribution of the values of the respective input components. The relationship between dimensions could be analyzed by visually comparing the patterns of the neurons in each dimension. The similarity of the patterns indicates a 
strong monotonic relationship between the dimensions.

First, we are concerned with the relationship between per capita ECF and per capita disposable income. In Figure 5, we observe that the pattern of panels e and $\mathrm{f}$ is almost consistent, which means that the per capita ECF is positively related to per capita disposable income. In general, higher income will lead to higher emissions. Thus, hypothesis 2 is supported. Subsequently we will provide details of the ECF in the four groups, namely, 1) food and clothing, 2) housing, 3) health, education and recreation, and 4) transport.

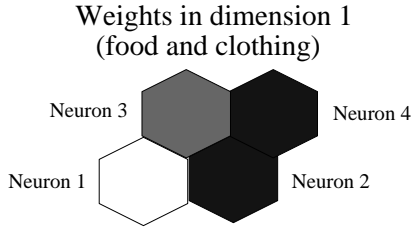

Panel a

Weights in dimension 3 (health, education and recreation)

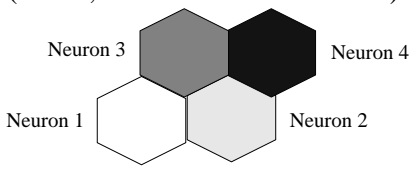

Panel c

Weights in dimension 5 (per capita ECF)

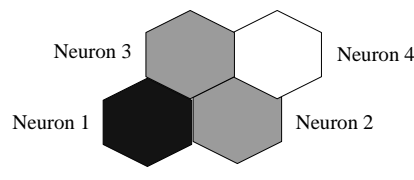

Panel e

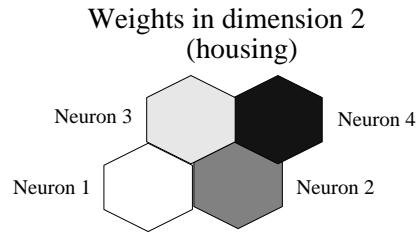

Panel b

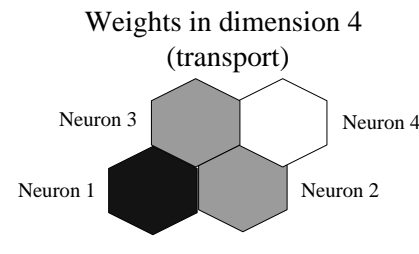

Panel d

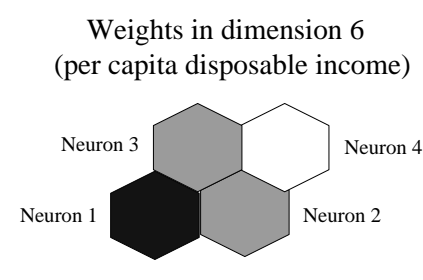

Panel $\mathrm{f}$

Source: Authors’ own calculation and the weights are generated in MATLAB R2008a.

Figure 5 Neuron weight characteristics of six conceptual dimensions

\section{The ECF of food and clothing}

Although the carbon emission intensity of food and clothing is not high, this group accounts for about $25 \%$ of total emissions (Table 1). China is still a developing country, and as a result subsistence-oriented emissions account for a large chunk. For example, food remains a very important component in the Chinese households' ECF. 
In contrast, the average share of food ECF in US households is only 6.9\% (Shammim, 2012).

As shown in Figure 5, neuron 1 in panel a is brighter. However it is darker in panel f. Similarly, neuron 4 in panel a is darker while it is brighter in panel f. Thus, the structure of panels a and $\mathrm{f}$ in Figure 5 is complementary, which shows that the ECF share of food and clothing is negatively related to per capita disposable income. As the level of per capita disposable income increases, the proportion of emissions from necessity consumption such as food and clothing will gradually decrease. Consumers' disposable income is considered an important factor in shaping the structure of their consumption patterns. An increase in income is usually perceived as the major driver of changes in the volume and structure of the food consumed. According to Engel's law, richer households spend less of their budgets on food than poorer households (Égert, 2011).

In panel a of Figure 5, if we regard the color of neuron 2 as a benchmark, the color of neuron 3 should be the same as neuron 2. However this is not the case (shown in panel a, Figure 5). Comparing Inner Mongolia, which is the minimum (or the region with the lowest ECF share) in neuron 2, with Shandong, which is the maximum (or the region with the highest ECF share) in neuron 3, the ECF share of food and clothing in Shandong is higher than that in Inner Mongolia (Table 1). However the disposable income of Shandong is also higher than that of Inner Mongolia, which seems to be inconsistent with the argument in the preceding paragraph. From a specific consumption item, we can find that the sum of the ECF of aquatic products, poultries and eggs in Shandong is 2.7 times as high as that in Inner Mongolia (Table 3). This is mainly due to the difference of dietary habits. Shandong cuisine is one of the Eight Cuisines of China whereas Inner Mongolia is located in the northwest of China with different dietary habits. Thus different dietary habits shape different demands for aquatic products and poultry causing the difference in their ECF. In summary, the above analysis shows that per capita disposable income is negatively related to the ECF share of food and clothing. In addition, dietary habit can also be regarded as a main influencing factor. Thus, hypothesis 3 is supported. 
Table 3 ECF per capita of each consumption item (unit: kg)

\begin{tabular}{|c|c|c|c|c|c|}
\hline $\begin{array}{c}\text { ECF } \\
\text { categories }\end{array}$ & Consumption items & Shandong & $\begin{array}{c}\text { Inner } \\
\text { Mongolia }\end{array}$ & Hunan & Guangxi \\
\hline \multirow{23}{*}{$\begin{array}{l}\text { ECF of } \\
\text { food and } \\
\text { clothing }\end{array}$} & Grain & 25.91 & 27.92 & 29.37 & 25.52 \\
\hline & Starches and Tubers & 2.82 & 2.23 & 1.65 & 1.74 \\
\hline & $\begin{array}{l}\text { Beans and Bean } \\
\text { Products }\end{array}$ & 3.71 & 2.50 & 4.89 & 4.09 \\
\hline & Oil and Fats & 9.78 & 7.25 & 14.86 & 10.93 \\
\hline & Meats & 43.37 & 44.03 & 54.27 & 67.76 \\
\hline & Poultries & 18.91 & 10.67 & 31.21 & 64.07 \\
\hline & Eggs & 21.18 & 9.90 & 10.53 & 10.80 \\
\hline & Aquatic Products & 43.03 & 9.77 & 28.63 & 39.90 \\
\hline & Vegetables & 49.29 & 38.59 & 59.69 & 50.45 \\
\hline & Condiments & 4.21 & 3.33 & 3.70 & 3.01 \\
\hline & Sugar & 2.59 & 2.18 & 3.34 & 3.56 \\
\hline & Tobacco & 9.11 & 17.25 & 16.77 & 8.60 \\
\hline & $\begin{array}{l}\text { Liquor and } \\
\text { Beverages }\end{array}$ & 18.65 & 17.35 & 11.45 & 9.83 \\
\hline & $\begin{array}{l}\text { Dried and Fresh } \\
\text { Fruits }\end{array}$ & 47.36 & 35.28 & 39.62 & 38.24 \\
\hline & Cake & 8.49 & 4.17 & 4.93 & 5.61 \\
\hline & Dairy Products & 19.73 & 13.31 & 10.68 & 11.81 \\
\hline & Other Foods & 8.47 & 16.83 & 9.79 & 6.71 \\
\hline & $\begin{array}{c}\text { Food Processing } \\
\text { Services }\end{array}$ & 0.04 & 0.03 & 0.03 & 0.05 \\
\hline & Dining Out & 30.34 & 34.20 & 32.48 & 34.09 \\
\hline & Garments & 18.13 & 20.43 & 15.20 & 10.04 \\
\hline & Clothing Materials & 1.64 & 1.03 & 1.49 & 1.26 \\
\hline & Shoes & 5.81 & 6.40 & 4.81 & 2.87 \\
\hline & $\begin{array}{l}\text { Tailoring and } \\
\text { Laundering }\end{array}$ & 1.27 & 1.74 & 0.70 & 0.41 \\
\hline \multirow{12}{*}{$\begin{array}{c}\text { ECF of } \\
\text { housing } \\
\text { (including } \\
\text { residential } \\
\text { energy) }\end{array}$} & Houses & 7.14 & 7.10 & 5.74 & 4.81 \\
\hline & Water & 5.80 & 3.48 & 7.89 & 8.60 \\
\hline & Electricity & 279.48 & 217.77 & 368.90 & 333.23 \\
\hline & Fuels & 69.62 & 31.26 & 53.57 & 44.30 \\
\hline & Heating & 268.50 & 286.11 & 1.81 & 0.41 \\
\hline & Residential services & 1.26 & 1.92 & 0.88 & 0.91 \\
\hline & Durables & 11.63 & 8.20 & 7.83 & 7.35 \\
\hline & Articles for Interior & 1.59 & 1.45 & 0.93 & 0.37 \\
\hline & Bed Articles & 0.95 & 1.09 & 1.17 & 0.78 \\
\hline & Household Articles & 10.62 & 10.76 & 12.33 & 9.63 \\
\hline & Furniture Materials & 0.42 & 0.55 & 0.38 & 0.52 \\
\hline & Household Services & 0.49 & 0.52 & 1.05 & 0.62 \\
\hline
\end{tabular}




\begin{tabular}{|c|c|c|c|c|c|}
\hline & $\begin{array}{l}\text { Other Goods } \\
\text { Other Services }\end{array}$ & $\begin{array}{c}12.33 \\
2.37\end{array}$ & $\begin{array}{c}16.99 \\
3.74\end{array}$ & $\begin{array}{c}10.94 \\
2.75\end{array}$ & $\begin{array}{l}9.32 \\
2.55\end{array}$ \\
\hline $\begin{array}{l}\text { ECF of } \\
\text { health, }\end{array}$ & $\begin{array}{c}\text { Health Care and } \\
\text { Medical }\end{array}$ & 411.91 & 487.08 & 473.33 & 370.92 \\
\hline education & Recreation Articles & 5.96 & 5.47 & 4.47 & 4.68 \\
\hline and & Recreation Services & 4.33 & 6.32 & 6.97 & 5.59 \\
\hline recreation & Education & 23.06 & 12.63 & 13.41 & 19.49 \\
\hline $\begin{array}{l}\text { ECF of } \\
\text { transport }\end{array}$ & $\begin{array}{c}\text { Transport } \\
\text { Communications }\end{array}$ & $\begin{array}{c}209.94 \\
13.64\end{array}$ & $\begin{array}{c}204.06 \\
14.00\end{array}$ & $\begin{array}{c}180.66 \\
14.20\end{array}$ & $\begin{array}{c}168.34 \\
11.18\end{array}$ \\
\hline
\end{tabular}

Source: Authors’ own calculation.

\section{The ECF of housing}

At the national level, the ECF of housing consumption accounts for 33\% of the total ECF (Table 1), which is similar to the result of Fan et al. (2012) who reported a 24 to 31\% share of the overall ECF. For comparison, the average share of US housing ECF (including residential energy ECF) is 45.5\% (Shammim, 2012). In 1991 the Chinese State Council proposed changing the low rent of public houses and capitalizing gradually on housing allocation instead of welfare housing allocation as the goals of the housing system reform (Zhou, 2011). As a consequence, these reforms have helped the real estate sector expand rapidly and buying a house has become an important step for improving living standards in China (Fan, et al., 2012).

As shown in Figure 5, neuron 1 in panel b is brighter. However it is darker in panel f. Similarly, neuron 4 in panel b is darker while it is brighter in panel $\mathrm{f}$. According to section 4, we can conclude that dimensions 2 and 6 are complementary, which indicates that the ECF share of housing is negatively related to per capita disposable income. The compact city theory can explain this result. The distribution densities of cities in eastern China (rich regions) and in middle China are respectively 13.1 times and 5.8 times as high as those in western China (Yue et al., 2005). The supporters of the compact city theory (for example, Jacobs, 1961; Newman and Kenworthy, 1989) believe that a compact city has the environmental and energy advantage. The main justification for the compact city is that it results in the least energy-intensive activity pattern, thereby helping us cope with the issues of global 
warming (Holden and Norland, 2005).

In panel $\mathrm{f}$ of Figure 5, the color of neurons 2 and 3 is similar. According to above correlation analysis, the color of them will also be similar in panel b. However this is not the case and the color of neuron 3 is brighter than that of neuron 2 (shown in panel b, Figure 5). Comparing Shandong, which is the maximum in neurons 3, with Guangxi, which represents the minimum of neurons 2, the per capita disposable income of Shandong is higher than that of Guangxi (Tables 1 and 2). However the ECF share of housing in Shandong is also higher than that in Guangxi (Table 1). In terms of specific consumption items, the main difference appears to be found in heating (Table 3). The ECF of family heating in Shandong (268.50 kg) is obviously higher than that in Guangxi (0.41 kg), implying that the geographic location (latitude) is closely related to per capita ECF.

In northern Chinese cities (north to the Qinling Mountains-Huai River line such as Shandong), heating is provided by the centralized heating system between November 15 and March 15 (Zheng et al., 2010). This system is highly subsidized by the government. Such a government-provided heating system does not exist in southern China. In summary, per capita disposable income shows a negative relationship with the housing ECF share. Besides disposable income, geographic location can also be regarded as the main influencing factors. Thus, hypothesis 3 is supported.

\section{The ECF of health, education and recreation}

Cultural and recreation services including paper production require high-energy consumption (Feng et al., 2011). At the national level, the ECF of health, education and recreation on average accounts for $28 \%$ of the total ECF (Table 1). As shown in Figure 5, neuron 1 is the brightest in panel c while it is the darkest in panel f. Neuron 4 is the darkest in panel c. In contrast, it is the brightest in panel f. According to section 4, we can conclude that dimensions 3 and 6 are complementary, which indicates that per capita disposable income shows a negative relationship with the ECF share of health, education and recreation. The level of social security (such as 
health and basic education) is much lower in western China than in eastern China (Hebei Provincial Government, 2009). So households in western China would have to spend a higher proportion of their income on health and education.

Comparing Hunan, which is the maximum in neurons 2, with Shandong which is the minimum in neurons 3, the ECF share of health, education and recreation of Hunan is higher than that of Shandong although the per capita disposable income of Hunan is lower than that of Shandong. In terms of specific consumption items, the main difference appears in entertainment activities, which can be attributed to the leisure culture of Hunan (MCPRC, 2005). In total, per capita disposable income shows a negative relationship with the ECF share. Except for disposable income, leisure culture could also be regarded as a main influencing factor.

\section{The ECF of transport}

The emission intensity of transport is the highest in all types of consumption. At the national level, transport ECF accounts for $14 \%$ of the total ECF. This share is still much lower in China than that in the US where the share of transport alone is more than 35\% of household emissions (Shammim, 2012). Panel d in Figure 5 is basically consistent with panel $\mathrm{f}$ in Figure 5, indicating that per capita disposable income shows a positive relationship with the ECF share. This finding is in line with the results of Fan et al. (2012).

Transport is a fundamental prerequisite for a society's development and the improvement of people's life. However, the rising car ownership would increase the transport ECF. For example, despite strong control over vehicle ownership in Shanghai, emissions from the transportation sector have increased eightfold during the period 1985-2006 (Dhakal, 2009). Beijing recorded almost a sevenfold increase in the same period. Hence, transport activities should be at the core of carbon-reduction policies. 


\section{POLICY IMPLICATIONS}

Since the proportion of private transport ECF is positively related to per capita disposable income, the growth in transport activities may be one of the main drivers of GHGs in China. Therefore it is essential for the personal road transport sector to share the burden of emission reduction. To achieve this goal, several policies can be devised and discussed in theory and then tested in practice. A carbon tax for fuel (mainly gasoline and diesel) could be an effective approach for carbon reduction due to its simplicity and capability to provide an immediate carbon price signal (Avi-Yonah and Uhlmann, 2009). In addition to this policy, a consumption-based $\mathrm{CO}_{2}$ emissions quota system such as the personal carbon trading (PCT) scheme could also be introduced in the personal road transport sector (Wadud, 2011). Under such a system, each adult is allocated a tradable carbon allowance, which covers the carbon emitted from the fuel use of private vehicles (Fawcett, 2010). People who already live low carbon lives, invest in new-energy automobiles and travel less would have surpluses to sell for profit. Those who travel a lot or use energy-inefficient vehicles would need to buy extra allowances. It could be expected that a carbon tax or a PCT system would develop a price signal for carbon that incorporates the costs of that externality and drives the market toward finding acceptable alternatives such as low-carbon fuels, renewable energy and new-energy automobiles. These changes in demand could then be viewed more as business opportunities than burdens. For instance, higher demand is anticipated by utilities that have an energy portfolio with a relatively large share of renewable energy. Furthermore many strategic opportunities could arise in new product development. For example, a vehicle manufacturer would have an incentive to develop and produce more fuel-efficient vehicles since consumers will demand more fuel-efficient and carbon efficient vehicles.

\section{CONCLUSIONS}

This research shows that the spatial differentiation of urban residents' per capita ECF 
in China is significant, with the per capita ECF of the east coastal area at a high level, and that per capita disposable income is the key factor affecting ECF. These imply a need for policies to encourage consumers to purchase less carbon intensive products or services, to decrease the carbon intensity of consumption and increase the utilization of cleaner energy sources (such as wind, solar and natural gas). In addition, other main factors that influence the ECF include the geographic location the dietary habit and the leisure culture. However, the per capita ECF of the underdeveloped areas is still low, and necessities such as food and clothing account for a big chunk of this. Therefore, from the perspective of consumption, there is not much space for emission reduction in these areas. To avoid an overly general "one size fits all” policy, the east coastal areas should be considered as the main regions for carbon emission regulation.

\section{BIODATA OF THE CONTRIBUTORS}

Jin Fan is a post-doctoral fellow of School of Management of the University of Science and Technology of China and his primary research interests are environmental economics, and sustainable development in China. Yanrui $\mathrm{Wu}$ is Professor of Economics in Business School, the University of Western Australia. His research interests include Asian economies, environmental policy and economic growth. Xiumei Guo is a lecturer in Curtin University Sustainability Policy Institute. Her research covers China's environment, innovation and sustainable development. Dingtao Zhao is a professor of School of Management at University of Science and Technology of China and his primary research interests are environmental economics, and pollution management in China. Dora Marinova is Professor of Sustainability of Curtin University Sustainability Policy Institute. Her research interests include sustainability, environmental policy and economic development. 


\section{REFERENCES}

Abrahamse, W., and Steg, L., 2009. "How do socio-demographic and psychological factors relate to households' direct and indirect energy use and savings?” Journal of Economic Psychology, 30, 711-720.

Abrahamse, W., Steg, L., Vlek, C., and Rothengatter, T., 2007. "The effect of tailored information, goal setting, and tailored feedback on household energy use, energy-related behaviors, and behavioral antecedents." Journal of Environmental Psychology, 27, 265-276.

Adua, L., 2010. "To cool a sweltering earth: does energy efficiency improvement offset the climate impacts of lifestyle?” Energy Policy, 39, 5717-5732.

Avi-Yonah, R.S., and Uhlmann, D.M., 2009. "Combating global climate change: why a carbon tax is a better response to global warming than cap and trade." Stanford Environmental Law Journal, 28 (3), 3-50.

Bachu, R.G., Kopparthi, S., Adapa, B., and Barkana, B.D., 2008. "Separation of voiced and unvoiced using zero crossing rate and energy of the speech signal." Electrical Engineering Department, School of Engineering, University of Bridgeport.

Begum, R. A., Pereira, J. J., Jaafar, A. H., and Al-Amin, A. Q., 2009. “An empirical assessment of ecological footprint calculations for Malaysia.” Resources, Conservation and Recycling, 53, 582-587.

Benders, R.M.J., Kok, R., Moll, H.C., Wiersma, G., and Noorman, K.J., 2006. “New approaches for household energy conservation-In search of personal household energy budgets and energy reduction options.” Energy Policy, 34, 3612-3622.

Bicknell, K.B., Ball, R.J., Cullen, R., and Bigsby, H.R., 1998. "New methodology for the ecological footprint with an application to the New Zealand economy." Ecological Economics, 27, 149-160.

Crompton, P., and Wu, Y.R., 2005. "Energy consumption in China: past trends and future directions.” Energy Economics, 27, 195- 208.

Dhakal, S., 2009. "Urban energy use and carbon emissions from cities in China and policy implications.” Energy Policy, 37, 4208-4219.

Druckman, A., and Jackson, T., 2009. "The carbon footprint of UK households 19902004: a socio-economically disaggregated quasi-multi-regional input-output model.” Ecological Economics, 68, 2066-2077.

Das, A., and Paul, S.K., 2014. " $\mathrm{CO}_{2}$ emissions from household consumption in India between 1993-94 and 2006-07: a decomposition analysis.” Energy Economics, 41, 90-105.

Égert, B., 2011. "Catching-up and inflation in Europe: Balassa-Samuelson, Engel's Law and other culprits.” Economic Systems, 35, 208-229.

Fan, J., Guo, X.M., Marinova, D., Wu, Y.R., and Zhao, D.T., 2012. "Embedded carbon footprint of Chinese urban households: Structure and changes.” Journal of Cleaner Production, 33, 50-59.

Fan, J., Zhao, D.T., Wu, Y.R., and Wei, J.C., 2013. "Carbon pricing and electricity market reforms in China.” Clean Technologies and Environmental Policy, DOI 
10.1007/s10098-013-0691-6.

Fawcett, T., 2010. "Personal carbon trading: a policy ahead of its time?” Energy Policy, 38, 6868-6876.

Feng, Z.H., Zou, L.L., and Wei, Y.M., 2011. "The impact of household consumption on energy use and $\mathrm{CO}_{2}$ emissions in China.” Energy, 36, 656-670.

Ferng, J.J., 2001. "Using composition of land multiplier to estimate ecological footprints associated with production activity." Ecological Economics, 37, 159172.

Ferng, J.J., 2009. “Applying input-output analysis to scenario analysis of ecological footprints.” Ecological Economics, 69, 345-354.

Figge, F., Young, W., and Barkemeyer, R., 2014. "Sufficiency or efficiency to achieve lower resource consumption and emissions? The role of the rebound effect." Journal of Cleaner Production, 69, 216-224.

Hebei Provincial Government, 2009. "The existing problems and countermeasures of China's social security system.” http://www.hebei.gov.cn/article/20090916/1285246.htm (In Chinese).

Herrmann, I.T., and Hauschild, M.Z., 2009. "Effects of globalization on carbon footprints of products.” CIRP Annals - Manufacturing Technology, 58, 13-16.

Holden, E., and Norland, I., 2005. "Three challenges for the compact city as a sustainable urban form: household consumption of energy and transport in eight residential areas in the greater Oslo region.” Urban Studies, 42, 2145-2166.

Intergovernmental Panel on Climate Change (IPCC), 2006. "IPCC guidelines for national greenhouse gas inventories.” Prepared by the National Greenhouse Gas Inventories Programme, Eggleston, H.S., Buendia, L., Miwa, K., Ngara, T., Tanabe, K. (eds). IGES, Japan http://www.ipcc-nggip.iges.or.jp/public/2006gl/index.html (24.12.2011).

Jacobs, J., 1961. "The death and life of great American cities: the failure of town planning.” New York: Random House.

Kalteh, A.M., Hjorth, P., and Berndtsson, R., 2008. "Review of the self-organizing map (SOM) approach in water resources: analysis, modeling and application.” Environmental Modeling \& Software, 23, 835-845.

Kim, J., Wei S., and Ruys, H., 2003. "Segmenting the market of West Australian senior tourists using an artificial neural network." Tourism Management, 24, 25-34.

Kohonen, T., 1982. "Self-organized formation of topologically correct feature maps.” Biological Cybernetics, 43, 59-69.

Lenzen, M., Dey, C., and Foran, B., 2004. "Energy requirements of Sydney households.” Ecological Economics, 49, 375-399.

Lenzen, M., and Murray, S.A., 2001. "A modified ecological footprint method and its application to Australia.” Ecological Economics, 37, 229-255.

Li, Q.Q., Guo, R., Li, F.T., and Xia, B.B., 2012. "Integrated inventory-based carbon accounting for energy-induced emissions in Chongming eco-island of Shanghai, China.” Energy Policy, 10, 173-181.

Lu, R.S., and Lo, S.L., 2002. "Diagnosing reservoir water quality using self-organizing maps and fuzzy theory.” Water Research, 36, 2265-2274. 
Manne, A.S., and Richels, R.G., 1991. "Global $\mathrm{CO}_{2}$ emission reductions-the impacts of rising energy costs.” The Energy Journal, 12, 87-107.

Ministry of Commerce of the People's Republic of China (MCPRC), 2005. "Changsha, Hunan : the sudden emergence of the cultural industry." http://www.mofcom.gov.cn/aarticle/difang/hunan/200512/20051201224497.html (In Chinese).

Moreno, D., Marco, P., and Olmeda, I., 2006. “Self-organizing maps could improve the classification of Spanish mutual funds." European Journal of Operational Research, 147, 1039-1054.

Mostafa, M.M., 2010. “Clustering the ecological footprint of nations using Kohonen's self-organizing maps.” Expert Systems with Applications, 4, 2747-2755.

National Bureau of Statistics of China (NBSC), 2008. "China energy statistical yearbook 2007.” China Statistics Press, Beijing (in Chinese).

National Bureau of Statistics of China (NBSC), 2008. "China urban life and price yearbook 2007.” China Statistics Press, Beijing (in Chinese).

National Bureau of Statistics of China (NBSC), 2012. "The statistical bulletin of the national economy and social development in 2011.” China Statistics Press, Beijing (in Chinese).

National Bureau of Statistics of China (NBSC), 2013. "China statistical yearbook 2013.” China Statistics Press, Beijing (in Chinese).

National Development and Reform Commission of China (NDRC), 2011. "Outline of the 12th Five-Year Plan of national economic and social development of the People's Republic of China.” (In Chinese).

Newman, P.W.G., and Kenworthy, J.R., 1989. "Gasoline consumption and cities: a comparison of US cities with a global survey." Journal of the American Planning Association, 55 (1), 24-37.

Olivier, J.G.J., and Peters, J.A.H.W., 2010. "No growth in total global $\mathrm{CO}_{2}$ emissions in 2009." Netherlands Environmental Assessment Agency, Bilthoven, The Netherlands.

Pachauri, S., 2004. "An analysis of cross-sectional variations in total household energy requirements in India using micro survey data.” Energy policy, 32, 17231735.

Reinders, A.H.M.E., Vringer, K., and Blok, K., 2003. "The direct and indirect energy requirement of households in the European Union.” Energy Policy, 31, 139-153.

Rood, G.A., Ros, J.P.M., Drissen, E., and Vringer, K., 2003. "A structure of models for future projections of environmental pressure due to consumption." Journal of Cleaner Production, 11, 491-498.

Shammim, M.R., 2012. "The role of US households in global carbon emissions.” In: Liu, G. (Ed.), Greenhouse Gases Emission, Measurement and Management. In TechOpen.

Ch.

8. http://cdn.intechopen.com/pdfs/32347/InTech-The_role_of_us_households_in_glob al_carbon_emissions.pdf.

Silver, H., and Shmoish, M., 2008. "Analysis of cognitive performance in schizophrenia patients and healthy individuals with unsupervised clustering models.” 
Psychiatry Research, 159, 167-179.

Steg, L., 2008. “Promoting household energy conservation.” Energy Policy, 36, 44494453.

Turner, K., Lenzen, M., Wiedmannc, T., and Barrett, J., 2007. "Examining the global environmental impact of regional consumption activities-Part 1: a technical note on combining input-output and ecological footprint analysis." Ecological Economics, 62, 37-44.

Vringer, K., and Blok, K., 1995. "The direct and indirect energy requirements of households in the Netherlands.” Energy Policy, 23, 893-910.

Vringer, K., and Blok, K., 2000. "Long-term trends in direct and indirect household energy intensities: a factor in dematerialization?” Energy Policy, 28, 713-727.

Wadud, Z., 2011. "Personal tradable carbon permits for road transport: why, why not and who wins?” Transportation Research Part A, 45, 1052-1065.

Wang, C., Cai, W., Lu, X., and Chen, J., 2007. " $\mathrm{CO}_{2}$ mitigation scenarios in China's road transport sector.” Energy Conversion and Management, 48 (7), 2110-2118.

Weber, C.L., and Matthews, H.S., 2008. "Quantifying the global and distributional aspects of American household carbon footprint.” Ecological Economics, 66, 379391.

Ying, B., Xia, N., Tong, W.T., Hu, L.Q., Du, P., Lu L.Y., and Yan, J.H., 2006. "Chinese Food Industry and Market Report."

Yue, T.X., Wang, Y.A., Liu, J.Y., Chen, S.P., Qiu, D.S., Deng, X.Z., Liu, M.L., Tian, Y.Z., and Su, B.P., 2005. "Surface modelling of human population distribution in China.” Ecological Modelling, 4, 461-478.

Zheng, S., Wang, R., Kahn, M.E., and Glaeser, E.L., 2011. "The greenness of China: household carbon dioxide emissions and urban development.” Journal of Economic Geography, 11, 761-792

Zhou, J.K., 2011. "Uncertainty and housing tenure choice by household types: evidence from China.” China Economic Review, 3, 408-427. 
Editor, UWA Economics Discussion Papers:

Sam Hak Kan Tang

University of Western Australia

35 Sterling Hwy

Crawley WA 6009

Australia

Email: ecoadmin@biz.uwa.edu.au

The Economics Discussion Papers are available at:

1980 - 2002: http://ecompapers.biz.uwa.edu.au/paper/PDF\%20of\%20Discussion\%20Papers/

Since 2001: http://ideas.repec.org/s/uwa/wpaper1.html

Since 2004: $\quad$ http://www.business.uwa.edu.au/school/disciplines/economics

\begin{tabular}{|c|c|c|}
\hline \multicolumn{3}{|c|}{$\begin{array}{c}\text { ECONOMICS DISCUSSION PAPERS } \\
2013\end{array}$} \\
\hline $\begin{array}{l}\text { DP } \\
\text { NUMBER }\end{array}$ & AUTHORS & TITLE \\
\hline 13.01 & $\begin{array}{l}\text { Chen, M., Clements, K.W. and } \\
\text { Gao, G. }\end{array}$ & THREE FACTS ABOUT WORLD METAL PRICES \\
\hline 13.02 & Collins, J. and Richards, O. & $\begin{array}{l}\text { EVOLUTION, FERTILITY AND THE AGEING } \\
\text { POPULATION }\end{array}$ \\
\hline 13.03 & $\begin{array}{l}\text { Clements, K., Genberg, H., Harberger, } \\
\text { A., Lothian, J., } \\
\text { Mundell, R., Sonnenschein, H. and } \\
\text { Tolley, G. }\end{array}$ & LARRY SJAASTAD, 1934-2012 \\
\hline 13.04 & Robitaille, M.C. and Chatterjee, I. & MOTHERS-IN-LAW AND SON PREFERENCE IN INDIA \\
\hline 13.05 & Clements, K.W. and Izan, I.H.Y. & $\begin{array}{l}\text { REPORT ON THE } 25^{\mathrm{TH}} \text { PHD CONFERENCE IN } \\
\text { ECONOMICS AND BUSINESS }\end{array}$ \\
\hline 13.06 & Walker, A. and Tyers, R. & QUANTIFYING AUSTRALIA’S “THREE SPEED” BOOM \\
\hline 13.07 & Yu, F. and Wu, Y. & PATENT EXAMINATION AND DISGUISED PROTECTION \\
\hline 13.08 & $\mathrm{Yu}, \mathrm{F}$. and $\mathrm{Wu}, \mathrm{Y}$. & $\begin{array}{l}\text { PATENT CITATIONS AND KNOWLEDGE SPILLOVERS: } \\
\text { AN ANALYSIS OF CHINESE PATENTS REGISTER IN THE } \\
\text { US }\end{array}$ \\
\hline 13.09 & Chatterjee, I. and Saha, B. & BARGAINING DELEGATION IN MONOPOLY \\
\hline 13.10 & Cheong, T.S. and Wu, Y. & $\begin{array}{l}\text { GLOBALIZATION AND REGIONAL INEQUALITY IN } \\
\text { CHINA }\end{array}$ \\
\hline 13.11 & Cheong, T.S. and Wu, Y. & INEQUALITY AND CRIME RATES IN CHINA \\
\hline 13.12 & Robertson, P.E. and Ye, L. & ON THE EXISTENCE OF A MIDDLE INCOME TRAP \\
\hline 13.13 & Robertson, P.E. & THE GLOBAL IMPACT OF CHINA'S GROWTH \\
\hline 13.14 & $\begin{array}{l}\text { Hanaki, N., Jacquemet, N., } \\
\text { Luchini, S., and Zylbersztejn, A. }\end{array}$ & $\begin{array}{l}\text { BOUNDED RATIONALITY AND STRATEGIC } \\
\text { UNCERTAINTY IN A SIMPLE DOMINANCE SOLVABLE } \\
\text { GAME }\end{array}$ \\
\hline 13.15 & $\begin{array}{l}\text { Okatch, Z., Siddique, A. and } \\
\text { Rammohan, A. }\end{array}$ & $\begin{array}{l}\text { DETERMINANTS OF INCOME INEQUALITY IN } \\
\text { BOTSWANA }\end{array}$ \\
\hline 13.16 & Clements, K.W. and Gao, G. & $\begin{array}{l}\text { A MULTI-MARKET APPROACH TO MEASURING THE } \\
\text { CYCLE }\end{array}$ \\
\hline
\end{tabular}




\begin{tabular}{|c|c|c|}
\hline 13.17 & Chatterjee, I. and Ray, R. & $\begin{array}{l}\text { THE ROLE OF INSTITUTIONS IN THE INCIDENCE OF } \\
\text { CRIME AND CORRUPTION }\end{array}$ \\
\hline 13.18 & Fu, D. and Wu, Y. & $\begin{array}{l}\text { EXPORT SURVIVAL PATTERN AND DETERMINANTS } \\
\text { OF CHINESE MANUFACTURING FIRMS }\end{array}$ \\
\hline 13.19 & Shi, X., Wu, Y. and Zhao, D. & $\begin{array}{l}\text { KNOWLEDGE INTENSIVE BUSINESS SERVICES AND } \\
\text { THEIR IMPACT ON INNOVATION IN CHINA }\end{array}$ \\
\hline 13.20 & $\begin{array}{l}\text { Tyers, R., Zhang, Y. and } \\
\text { Cheong, T.S. }\end{array}$ & $\begin{array}{l}\text { CHINA'S SAVING AND GLOBAL ECONOMIC } \\
\text { PERFORMANCE }\end{array}$ \\
\hline 13.21 & Collins, J., Baer, B. and Weber, E.J. & $\begin{array}{l}\text { POPULATION, TECHNOLOGICAL PROGRESS AND THE } \\
\text { EVOLUTION OF INNOVATIVE POTENTIAL }\end{array}$ \\
\hline 13.22 & Hartley, P.R. & THE FUTURE OF LONG-TERM LNG CONTRACTS \\
\hline 13.23 & Tyers, R. & $\begin{array}{l}\text { A SIMPLE MODEL TO STUDY GLOBAL } \\
\text { MACROECONOMIC INTERDEPENDENCE }\end{array}$ \\
\hline 13.24 & McLure, M. & $\begin{array}{l}\text { REFLECTIONS ON THE QUANTITY THEORY: PIGOU IN } \\
1917 \text { AND PARETO IN 1920-21 }\end{array}$ \\
\hline 13.25 & Chen, A. and Groenewold, N. & $\begin{array}{l}\text { REGIONAL EFFECTS OF AN EMISSIONS-REDUCTION } \\
\text { POLICY IN CHINA: THE IMPORTANCE OF THE } \\
\text { GOVERNMENT FINANCING METHOD }\end{array}$ \\
\hline 13.26 & Siddique, M.A.B. & $\begin{array}{l}\text { TRADE RELATIONS BETWEEN AUSTRALIA AND } \\
\text { THAILAND: } 1990 \text { TO } 2011\end{array}$ \\
\hline 13.27 & Li, B. and Zhang, J. & $\begin{array}{l}\text { GOVERNMENT DEBT IN AN INTERGENERATIONAL } \\
\text { MODEL OF ECONOMIC GROWTH, ENDOGENOUS } \\
\text { FERTILITY, AND ELASTIC LABOR WITH AN } \\
\text { APPLICATION TO JAPAN }\end{array}$ \\
\hline 13.28 & Robitaille, M. and Chatterjee, I. & $\begin{array}{l}\text { SEX-SELECTIVE ABORTIONS AND INFANT } \\
\text { MORTALITY IN INDIA: THE ROLE OF PARENTS' } \\
\text { STATED SON PREFERENCE }\end{array}$ \\
\hline 13.29 & Ezzati, P. & $\begin{array}{l}\text { ANALYSIS OF VOLATILITY SPILLOVER EFFECTS: } \\
\text { TWO-STAGE PROCEDURE BASED ON A MODIFIED } \\
\text { GARCH-M }\end{array}$ \\
\hline 13.30 & Robertson, P. E. & $\begin{array}{l}\text { DOES A FREE MARKET ECONOMY MAKE AUSTRALIA } \\
\text { MORE OR LESS SECURE IN A GLOBALISED WORLD? }\end{array}$ \\
\hline 13.31 & $\begin{array}{l}\text { Das, S., Ghate, C. and } \\
\text { Robertson, P. E. }\end{array}$ & $\begin{array}{l}\text { REMOTENESS AND UNBALANCED GROWTH: } \\
\text { UNDERSTANDING DIVERGENCE ACROSS INDIAN } \\
\text { DISTRICTS }\end{array}$ \\
\hline 13.32 & Robertson, P.E. and Sin, A. & $\begin{array}{l}\text { MEASURING HARD POWER: CHINA'S ECONOMIC } \\
\text { GROWTH AND MILITARY CAPACITY }\end{array}$ \\
\hline 13.33 & $\mathrm{Wu}, \mathrm{Y}$. & $\begin{array}{l}\text { TRENDS AND PROSPECTS FOR THE RENEWABLE } \\
\text { ENERGY SECTOR IN THE EAS REGION }\end{array}$ \\
\hline 13.34 & $\begin{array}{l}\text { Yang, S., Zhao, D., Wu, Y. and } \\
\text { Fan, J. }\end{array}$ & $\begin{array}{l}\text { REGIONAL VARIATION IN CARBON EMISSION AND ITS } \\
\text { DRIVING FORCES IN CHINA: AN INDEX } \\
\text { DECOMPOSITION ANALYSIS }\end{array}$ \\
\hline
\end{tabular}




\begin{tabular}{|c|c|c|}
\hline \multicolumn{3}{|c|}{$\begin{array}{l}\text { ECONOMICS DISCUSSION PAPERS } \\
2014\end{array}$} \\
\hline $\begin{array}{l}\text { DP } \\
\text { NUMBER }\end{array}$ & AUTHORS & TITLE \\
\hline 14.01 & $\begin{array}{l}\text { Boediono, Vice President of the Republic } \\
\text { of Indonesia }\end{array}$ & $\begin{array}{l}\text { THE CHALLENGES OF POLICY MAKING IN A } \\
\text { YOUNG DEMOCRACY: THE CASE OF INDONESIA } \\
\text { (52ND SHANN MEMORIAL LECTURE, 2013) }\end{array}$ \\
\hline 14.02 & Metaxas, P.E. and Weber, E.J. & $\begin{array}{l}\text { AN AUSTRALIAN CONTRIBUTION TO } \\
\text { INTERNATIONAL TRADE THEORY: THE } \\
\text { DEPENDENT ECONOMY MODEL }\end{array}$ \\
\hline 14.03 & Fan, J., Zhao, D., Wu, Y. and Wei, J. & $\begin{array}{l}\text { CARBON PRICING AND ELECTRICITY MARKET } \\
\text { REFORMS IN CHINA }\end{array}$ \\
\hline 14.04 & McLure, M. & $\begin{array}{l}\text { A.C. PIGOU’S MEMBERSHIP OF THE } \\
\text { ‘CHAMBERLAIN-BRADBURY’ COMMITTEE. } \\
\text { PART I: THE HISTORICAL CONTEXT }\end{array}$ \\
\hline 14.05 & McLure, M. & $\begin{array}{l}\text { A.C. PIGOU'S MEMBERSHIP OF THE } \\
\text { 'CHAMBERLAIN-BRADBURY’ COMMITTEE. } \\
\text { PART II: 'TRANSITIONAL’AND ‘ONGOING' ISSUES }\end{array}$ \\
\hline 14.06 & King, J.E. and McLure, M. & HISTORY OF THE CONCEPT OF VALUE \\
\hline 14.07 & Williams, A. & $\begin{array}{l}\text { A GLOBAL INDEX OF INFORMATION AND } \\
\text { POLITICAL TRANSPARENCY }\end{array}$ \\
\hline 14.08 & Knight, K. & $\begin{array}{l}\text { A.C. PIGOU’S THE THEORY OF UNEMPLOYMENT } \\
\text { AND ITS CORRIGENDA: THE LETTERS OF } \\
\text { MAURICE ALLEN, ARTHUR L. BOWLEY, RICHARD } \\
\text { KAHN AND DENNIS ROBERTSON }\end{array}$ \\
\hline 14.09 & Cheong, T.S. and Wu, Y. & $\begin{array}{l}\text { THE IMPACTS OF STRUCTURAL RANSFORMATION } \\
\text { AND INDUSTRIAL UPGRADING ON REGIONAL } \\
\text { INEQUALITY IN CHINA }\end{array}$ \\
\hline 14.10 & $\begin{array}{l}\text { Chowdhury, M.H., Dewan, M.N.A., } \\
\text { Quaddus, M., Naude, M. and } \\
\text { Siddique, A. }\end{array}$ & $\begin{array}{l}\text { GENDER EQUALITY AND SUSTAINABLE } \\
\text { DEVELOPMENT WITH A FOCUS ON THE COASTAL } \\
\text { FISHING COMMUNITY OF BANGLADESH }\end{array}$ \\
\hline 14.11 & Bon, J. & $\begin{array}{l}\text { UWA DISCUSSION PAPERS IN ECONOMICS: THE } \\
\text { FIRST } 750\end{array}$ \\
\hline 14.12 & Finlay, K. and Magnusson, L.M. & $\begin{array}{l}\text { BOOTSTRAP METHODS FOR INFERENCE WITH } \\
\text { CLUSTER-SAMPLE IV MODELS }\end{array}$ \\
\hline 14.13 & Chen, A. and Groenewold, N. & $\begin{array}{l}\text { THE EFFECTS OF MACROECONOMIC SHOCKS ON } \\
\text { THE DISTRIBUTION OF PROVINCIAL OUTPUT IN } \\
\text { CHINA: ESTIMATES FROM A RESTRICTED VAR } \\
\text { MODEL }\end{array}$ \\
\hline 14.14 & Hartley, P.R. and Medlock III, K.B. & $\begin{array}{l}\text { THE VALLEY OF DEATH FOR NEW ENERGY } \\
\text { TECHNOLOGIES }\end{array}$ \\
\hline 14.15 & $\begin{array}{l}\text { Hartley, P.R., Medlock III, K.B., } \\
\text { Temzelides, T. and Zhang, X. }\end{array}$ & $\begin{array}{l}\text { LOCAL EMPLOYMENT IMPACT FROM COMPETING } \\
\text { ENERGY SOURCES: SHALE GAS VERSUS WIND } \\
\text { GENERATION IN TEXAS }\end{array}$ \\
\hline 14.16 & Tyers, R. and Zhang, Y. & $\begin{array}{l}\text { SHORT RUN EFFECTS OF THE ECONOMIC REFORM } \\
\text { AGENDA }\end{array}$ \\
\hline 14.17 & Clements, K.W., Si, J. and Simpson, T. & UNDERSTANDING NEW RESOURCE PROJECTS \\
\hline 14.18 & Tyers, R. & $\begin{array}{l}\text { SERVICE OLIGOPOLIES AND AUSTRALIA'S } \\
\text { ECONOMY-WIDE PERFORMANCE }\end{array}$ \\
\hline 14.19 & Tyers, R. and Zhang, Y. & $\begin{array}{l}\text { REAL EXCHANGE RATE DETERMINATION AND } \\
\text { THE CHINA PUZZLE }\end{array}$ \\
\hline
\end{tabular}




\begin{tabular}{|c|c|c|}
\hline \multicolumn{3}{|c|}{$\begin{array}{l}\text { ECONOMICS DISCUSSION PAPERS } \\
\qquad 2014\end{array}$} \\
\hline $\begin{array}{l}\text { DP } \\
\text { NUMBER }\end{array}$ & AUTHORS & TITLE \\
\hline 14.20 & Ingram, S.R. & $\begin{array}{l}\text { COMMODITY PRICE CHANGES ARE } \\
\text { CONCENTRATED AT THE END OF THE CYCLE }\end{array}$ \\
\hline 14.21 & Cheong, T.S. and Wu, Y. & $\begin{array}{l}\text { CHINA'S INDUSTRIAL OUTPUT: A COUNTY-LEVEL } \\
\text { STUDY USING A NEW FRAMEWORK OF } \\
\text { DISTRIBUTION DYNAMICS ANALYSIS }\end{array}$ \\
\hline 14.22 & $\begin{array}{l}\text { Siddique, M.A.B., Wibowo, H. and } \\
\text { Wu, Y. }\end{array}$ & $\begin{array}{l}\text { FISCAL DECENTRALISATION AND INEQUALITY IN } \\
\text { INDONESIA: 1999-2008 }\end{array}$ \\
\hline 14.23 & Tyers, R. & $\begin{array}{l}\text { ASYMMETRY IN BOOM-BUST SHOCKS: } \\
\text { AUSTRALIAN PERFORMANCE WITH OLIGOPOLY }\end{array}$ \\
\hline 14.24 & Arora, V., Tyers, R. and Zhang, Y. & $\begin{array}{l}\text { RECONSTRUCTING THE SAVINGS GLUT: THE } \\
\text { GLOBAL IMPLICATIONS OF ASIAN EXCESS } \\
\text { SAVING }\end{array}$ \\
\hline 14.25 & Tyers, R. & $\begin{array}{l}\text { INTERNATIONAL EFFECTS OF CHINA’S RISE AND } \\
\text { TRANSITION: NEOCLASSICAL AND KEYNESIAN } \\
\text { PERSPECTIVES }\end{array}$ \\
\hline 14.26 & Milton, S. and Siddique, M.A.B. & $\begin{array}{l}\text { TRADE CREATION AND DIVERSION UNDER THE } \\
\text { THAILAND-AUSTRALIA FREE TRADE AGREEMENT } \\
\text { (TAFTA) }\end{array}$ \\
\hline 14.27 & Clements, K.W. and Li, L. & VALUING RESOURCE INVESTMENTS \\
\hline 14.28 & Tyers, R. & $\begin{array}{l}\text { PESSIMISM SHOCKS IN A MODEL OF GLOBAL } \\
\text { MACROECONOMIC INTERDEPENDENCE }\end{array}$ \\
\hline 14.29 & Iqbal, K. and Siddique, M.A.B. & $\begin{array}{l}\text { THE IMPACT OF CLIMATE CHANGE ON } \\
\text { AGRICULTURAL PRODUCTIVITY: EVIDENCE } \\
\text { FROM PANEL DATA OF BANGLADESH }\end{array}$ \\
\hline 14.30 & Ezzati, P. & $\begin{array}{l}\text { MONETARY POLICY RESPONSES TO FOREIGN } \\
\text { FINANCIAL MARKET SHOCKS: APPLICATION OF A } \\
\text { MODIFIED OPEN-ECONOMY TAYLOR RULE }\end{array}$ \\
\hline 14.31 & Tang, S.H.K. and Leung, C.K.Y. & $\begin{array}{l}\text { THE DEEP HISTORICAL ROOTS OF } \\
\text { MACROECONOMIC VOLATILITY }\end{array}$ \\
\hline 14.32 & Arthmar, R. and McLure, M. & $\begin{array}{l}\text { PIGOU, DEL VECCHIO AND SRAFFA: THE } 1955 \\
\text { INTERNATIONAL ‘ANTONIO FELTRINELLI’ PRIZE } \\
\text { FOR THE ECONOMIC AND SOCIAL SCIENCES }\end{array}$ \\
\hline 14.33 & McLure, M. & $\begin{array}{l}\text { A-HISTORIAL ECONOMIC DYNAMICS: A BOOK } \\
\text { REVIEW }\end{array}$ \\
\hline 14.34 & Clements, K.W. and Gao, G. & $\begin{array}{l}\text { THE ROTTERDAM DEMAND MODEL HALF A } \\
\text { CENTURY ON }\end{array}$ \\
\hline
\end{tabular}




\begin{tabular}{|c|c|c|}
\hline \multicolumn{3}{|c|}{$\begin{array}{l}\text { ECONOMICS DISCUSSION PAPERS } \\
2015\end{array}$} \\
\hline $\begin{array}{l}\text { DP } \\
\text { NUMBER }\end{array}$ & AUTHORS & TITLE \\
\hline 15.01 & Robertson, P.E. and Robitaille, M.C. & $\begin{array}{l}\text { THE GRAVITY OF RESOURCES AND THE } \\
\text { TYRANNY OF DISTANCE }\end{array}$ \\
\hline 15.02 & Tyers, R. & $\begin{array}{l}\text { FINANCIAL INTEGRATION AND CHINA'S GLOBAL } \\
\text { IMPACT }\end{array}$ \\
\hline 15.03 & Clements, K.W. and Si, J. & $\begin{array}{l}\text { MORE ON THE PRICE-RESPONSIVENESS OF FOOD } \\
\text { CONSUMPTION }\end{array}$ \\
\hline 15.04 & Tang, S.H.K. & $\begin{array}{l}\text { PARENTS, MIGRANT DOMESTIC WORKERS, AND } \\
\text { CHILDREN'S SPEAKING OF A SECOND } \\
\text { LANGUAGE: EVIDENCE FROM HONG KONG }\end{array}$ \\
\hline 15.05 & Tyers, R. & $\begin{array}{l}\text { CHINA AND GLOBAL MACROECONOMIC } \\
\text { INTERDEPENDENCE }\end{array}$ \\
\hline 15.06 & $\begin{array}{l}\text { Fan, J., Wu, Y., Guo, X., Zhao, D. and } \\
\text { Marinova, D. }\end{array}$ & $\begin{array}{l}\text { REGIONAL DISPARITY OF EMBEDDED CARBON } \\
\text { FOOTPRINT AND ITS SOURCES IN CHINA: A } \\
\text { CONSUMPTION PERSPECTIVE }\end{array}$ \\
\hline 15.07 & $\begin{array}{l}\text { Fan, J., Wang, S., Wu, Y., Li, J. and Zhao, } \\
\text { D. }\end{array}$ & $\begin{array}{l}\text { BUFFER EFFECT AND PRICE EFFECT OF A } \\
\text { PERSONAL CARBON TRADING SCHEME }\end{array}$ \\
\hline 15.08 & Neill, K. & $\begin{array}{l}\text { WESTERN AUSTRALIA'S DOMESTIC GAS } \\
\text { RESERVATION POLICY THE ELEMENTAL } \\
\text { ECONOMICS }\end{array}$ \\
\hline 15.09 & Collins, J., Baer, B. and Weber, E.J. & $\begin{array}{l}\text { THE EVOLUTIONARY FOUNDATIONS OF } \\
\text { ECONOMICS }\end{array}$ \\
\hline 15.10 & $\begin{array}{l}\text { Siddique, A., Selvanathan, E. A. and } \\
\text { Selvanathan, S. }\end{array}$ & $\begin{array}{l}\text { THE IMPACT OF EXTERNAL DEBT ON ECONOMIC } \\
\text { GROWTH: EMPIRICAL EVIDENCE FROM HIGHLY } \\
\text { INDEBTED POOR COUNTRIES }\end{array}$ \\
\hline 15.11 & Wu, Y. & $\begin{array}{l}\text { LOCAL GOVERNMENT DEBT AND ECONOMIC } \\
\text { GROWTH IN CHINA }\end{array}$ \\
\hline 15.12 & Tyers, R. and Bain, I. & $\begin{array}{l}\text { THE GLOBAL ECONOMIC IMPLICATIONS OF FREER } \\
\text { SKILLED MIGRATION }\end{array}$ \\
\hline 15.13 & Chen, A. and Groenewold, N. & $\begin{array}{l}\text { AN INCREASE IN THE RETIREMENT AGE IN CHINA: } \\
\text { THE REGIONAL ECONOMIC EFFECTS }\end{array}$ \\
\hline & & \\
\hline & & \\
\hline
\end{tabular}

